\title{
Pelatihan Pembuatan Media Pembelajaran Berbasis ICT Untuk Meningkatkan Kompetensi Guru PPKn SMP
}

\author{
Muhammad Japar, Irawaty, Syifa Syarifa, Dini Nur Fadhillah. \\ Program Studi Pendidikan Pancasila dan Kewarganegaraan, Universitas Negeri Jakarta, \\ Indonesia \\ Email : mjapar@unj.ac.id
}

\begin{abstract}
ABSTRAK
Information and Communication Technology (ICT) telah dimanfaatkan sebagai media pembelajaran yang bertujuan untuk menunjang pembelajaran yang interaktif, efektif dan efisien. Pemanfaatan media pembelajaran berbasis ICT sangat penting bagi pembelajaran PPKn di jenjang SMP yang selama ini terkesan tekstual dan membosankan. Salah satu penyebabnya adalah terbatasnya kemampuan guru PPKn SMP dalam memanfaatkan dan membuat media pembelajaran berbasis ICT. Solusi yang dapat dilakukan untuk mengatasi permasalahan ini adalah dengan menyelenggarakan pelatihan dan pendampingan pembuatan media pembelajaran berbasis ICT untuk meningkatkan kompetensi guru PPKn SMP. Metode pelaksanaan ditempuh melalui beberapa tahapan, yaitu : 1) mengidentifikasi dan menganalisis pemahaman guru mengenai ICT melalui artikel-artikel dan pengamatan secara langsung; 2) merumuskan strategi pelaksanaan pelatihan yang tepat; 3) melaksanakan pelatihan dengan melibatkan guru-guru PPKn SMP melalui aplikasi Zoom; 4) Presentasi, diskusi dan praktik pembuatan media pembelajaran berbasis ICT; 5) menyebarkan kuesioner evaluasi kegiatan; dan 6) mengevaluasi kegiatan. Pelatihan ini berlangsung dengan lancar dan mendapatkan respon yang baik dari peserta. Pelatihan ini diharapkan dapat meningkatkan kompetensi guru PPKn SMP khususnya dalam membuat media pembelajaran berbasis ICT.
\end{abstract}

Kata Kunci : ICT, PPKn,Pelatihan Media Pembelajaran.

\section{PENDAHULUAN}

Dalam penyelenggaraan pembelajaran, terdapat lima komponen penting yang saling mempengaruhi yaitu: tujuan, materi, metode, media, dan evaluasi pembelajaran. Salah satu komponen yang paling penting dan menunjang hasil pembelajaran adalah media pembelajaran. Media pembelajaran merupakan segala sesuatu yang dapat digunakan untuk menyalurkan pesan dari pendidik kepada peserta didik, sehingga dapat merangsang pikiran, perasaan, perhatian dan minat mereka untuk belajar (Tafonao, 2018). Media pembelajaran merupakan alat bantu dari proses pembelajaran yang sangat memegang peranan penting dalam kelangsungan proses belajar mengajar baik pembelajaran formal maupun non formal (Rosdiana, 2016). Pemakaian media pembelajaran dalam proses belajar mengajar dapat membangkitkan minat dan keinginan yang baru, membangkitkan motivasi dan rangsangan kegiatan belajar, dan bahkan membawa pengaruh-pengaruh psikologis terhadap pembelajar (Falahudin, 2014).

Media pembelajaran yang marak digunakan saat ini adalah media pembelajaran berbasis Information and Communication Technology (ICT) atau Teknologi Informasi dan Komunikasi (TIK). Kemajuan teknologi merupakan konsekuensi logis dari perkembangan zaman dan telah mempengaruhi kehidupan manusia dalam berbagai aspek, termasuk aspek pendidikan. Dengan integrasi ICT di kelas, peserta didik akan dapat terlibat dalam tugas-tugas interaktif dengan jangkauan informasi dan pengetahuan yang lebih luas selama pembelajaran mereka (Ghavifekr, et al., 2014). Aplikasi media teknologi pendidikan dalam pengajaran dan 
pembelajaran juga membantu guru mengomunikasikan informasi yang menarik bagi siswa (Sakat, et al., 2012). ICT digunakan sebagai istilah umum yang mencakup perangkat komunikasi atau aplikasi apa pun yang mencakup radio, televisi, telepon seluler, komputer, laptop, perangkat keras dan perangkat lunak, sistem satelit, internet dan beragamnya aplikasi yang terkait seperti telekonferensi, konferensi video, laboratorium virtual, perpustakaan digital dll (Singh \& Jabeen, 2018). ICT telah memungkinkan komunikasi yang lebih baik dan lebih cepat; presentasi ide lebih efektif dan cara yang relevan (Bhattacharjee \& Deb, 2016). Jadi, dapat disimpulkan bahwa media pembelajaran berbasis ICT yaitu media pembelajaran yang mana semua teknologi yang berhubungan dengan pengambilan, pengumpulan (akuisisi), pengolahan, penyimpanan, penyebaran, dan penyajian informasi/data dengan menggunakan komputer dan telekomunikasi (Suryani, Pengembangan Media Pembelajaran Berbasis IT, 2015).

ICT mencakup dua aspek, yaitu teknologi informasi dan teknologi komunikasi. Teknologi informasi meliputi segala hal yang berkaitan dengan proses, penggunaan sebagai alat bantu, manipulasi, dan pengelolaan informasi (Muslih, 2016). Sedangkan teknologi komunikasi adalah segala sesuatu yang berkaitan dengan penggunaan alat bantu untuk memproses dan mentransfer data dari perangkat yang satu ke lainnya (Rahim, 2011). Oleh karena itu, ICT memiliki makna yang luas yang mencakup seluruh teknologi untuk proses dan penyampaian informasi. Secara akademis, pengertian teknologi informasi dan teknologi komunikasi dapat dibedakan, akan tetapi pada prakteknya teknologi informasi dan komunikasi ibarat dua sisi mata uang, dimana keduanya sangat sulit dipisahkan (Budiana \& Bakri, 2015).

Pemanfaatan ICT sebagai media pembelajaran dapat menunjang terciptanya pembelajaran yang lebih interaktif, efektif dan efisien. Proses pembelajaran menjadi lebih menarik apabila menggunakan media yang tepat sehingga siswa termotivasi untuk mencintai ilmu pengetahuan yang sedang dipelajarinya (Nursamsu \& Kusnafizal, 2017). Pemanfaatan ICT dalam kegiatan pembelajaran sangat penting, khususnya bagi pembelajaran Pendidikan Pancasila dan Kewarganegaraan (PPKn) yang selama ini dianggap membosankan karena dinilai masih bersifat tekstual. Masih banyak guru PPKn yang hanya mengandalkan metode ceramah sehingga membuat peserta didik menjadi tidak tertarik untuk mempelajari PPKn. Bentuk pemanfaatan ICT dalam pembelajaran PPKn juga masih terbatas pada penggunaan Power Point secara sederhana saja. Padahal, penggunaan Power Point dapat ditingkatkan untuk mengakomodir pembelajaran PPKn yang sangat penting untuk mendidik dan membangun perilaku warga negara yang baik kepada peserta didik dalam kehidupan bermasyarakat, berbangsa dan bernegara. Selain itu, terdapat juga berbagai aplikasi yang dapat membantu kegiatan belajar mengajar agar tidak monoton dengan melaksanakan kuis. Beberapa aplikasi yang dapat digunakan adalah google classroom, Kahoot! dan bamboozle.

Selain itu, situasi pandemi Corona Virus Disease 2019 (COVID-19) yang kini terjadi di Indonesia mengharuskan para guru untuk memiliki keterampilan dalam memanfaatkan dan membuat media pembelajaran berbasis ICT. Hal ini dikarenakan kegiatan pembelajaran di kelas beralih menjadi Pembelajaran Jarak Jauh (PJJ) untuk sementara waktu. Agar media pembelajaran dapat dimanfaatkan dengan baik, guru perlu mengetahui kebutuhan pembelajarannya dan permasalahan-permasalahan yang dihadapi siswa tentang materi yang akan diajarkan (Karo Karo \& Rohani, 2018). Selain itu, sebelum membuat media pembelajaran berbasis ICT, guru harus memiliki keterampilan menggunakan teknologi dengan baik. Akan tetapi, kemajuan teknologi terkadang tidak berbanding lurus dengan keterampilan guru dalam memanfaatkannya. Sehingga pemanfaatan teknologi sebagai media dalam 
kegiatan pembelajaran menjadi kurang maksimal. Oleh karena itu, pengabdian ini mengangkat kegiatan dengan judul "Pelatihan dan Pendampingan Pembuatan Media Pembelajaran Berbasis ICT untuk memberikan pemahaman serta meningkatkan keterampilan guru dalam menggunakan dan memanfaatkan ICT dalam menciptakan pembelajaran yang efektif dan efisien".

\section{METODE PELAKSANAAN}

Pelatihan ini dilaksanakan dengan melalui beberapa langkah yaitu: 1) mengidentifikasi dan menganalisis terkait pemahaman guru mengenai ICT melalui artikel-artikel dan pengamatan sosial; 2) merumuskan strategi yang tepat dalam pelatihan yang akan dilaksanakan. 3) melaksanakan pelatihan dengan melibatkan guru-guru PPKn SMP melalui aplikasi Zoom; 4) Presentasi, diskusi dan praktik pembuatan media pembelajaran berbasis ICT; 5) menyebarkan kuesioner evaluasi kegiatan; 6) mengevaluasi kegiatan.

Analisis data menggunakan pendekatan kualitatif deskriptif. Adapun metode yang digunakan adalah kuesioner. Kuesioner merupakan teknik pengumpulan data yang dilakukan dengan cara memberi seperangkat pertanyaan atau pernyataan tertulis kepada responden untuk dijawabnya (Sugiyono, Metode Penelitian Kuantitatif, Kualitatif dan R\&D, 2011). Kuesioner disebarkan melalui Google Forms kepada 205 peserta pelatihan yang terbesar di berbagai wilayah yang ada di Indonesia. Pelaksanaan pelatihan dilakukan secara daring melalui aplikasi Zoom. Sementara itu, waktu penyelenggaraan pelatihan dilaksanakan pada tanggal 25 Juli 2020 pukul 09.00 s/d 12.00 WIB.

\section{HASIL DAN PEMBAHASAN}

Dunia pendidikan mulai meraih banyak manfaat dalam penggunaan dan pemanfaatan teknologi. Mulai dari eksplorasi materi-materi pelajaran yang berkualitas seperti literatur, jurnal dan buku, membangun forum-forum diskusi ilmiah, sampai konsultasi/diskusi dengan para pakar di dunia, semua ini dapat dimudahkan dan dilakukan tanpa mengalami batas karena manusia dapat melakukannya sendiri (Andriani, 2015). ICT dalam dunia pendidikan digunakan untuk menyelesaikan permasalahan pembelajaran dalam pendidikan sebagai upaya meningkatkan kualitas pendidikan. Penggunaan ICT sebagai media pembelajaran dapat berbentuk file slide Power Point, gambar, animasi, video, audio, program CAI (Computer Aided Instruction), program simulasi, dan lain-lain (Suryani, 2015).

Mata Pelajaran Pancasila dan Pendidikan Kewarganegaraan (PPKn) merupakan mata pelajaran yang menfokuskan pada pembentukan warga negara yang memahami dan mampu melaksanakan hak-hak dan kewajibannya untuk menjadi warga negara Indonesia yang cerdas, terampil, dan berkarakter yang diamanatkan oleh pancasila dan UUD 1945 (Bariyah, 2018). Pendidikan kewarganegaraan diartikan sebagai penyiapan generasi muda (siswa) untuk menjadi warga negara yang memiliki pengetahuan, kecakapan, dan nilai-nilai yang diperlukan untuk berpartisipasi aktif dalam masyarakatnya (Samsuri, 2011, h.28). Kenyataan di Indonesia saat ini, pembelajaran PKn masih didominasi oleh sistem konvensional, sehingga penerapan pembelajaran yang berorientasi pada konsep contextualized masih jauh dari harapan (Suhartono, 2018). Masih banyak guru PPKn yang hanya mengandalkan metode ceramah sehingga pembelajaran menjadi kurang interaktif dan terkesan berpusat pada guru (teacher centered learning). 
Selain itu, kemampuan guru PPKn masih terbatas dalam memanfaatkan dan membuat media pembelajaran berbasis ICT. Padahal, mata pelajaran PPKn di jenjang Sekolah Menengah Pertama (SMP) memuat banyak materi yang penting dalam pembentukan warga negara yang baik. Guru PPKn SMP harus mampu menyampaikan materi dengan baik dan dengan metode yang bervariatif dengan melibatkan peserta didik secara aktif misalnya dengan mengadakan kuis, sehingga materi tersebut dapat diterima dan dipahami dengan baik pula oleh peserta didik. Oleh karena itu, pelatihan ini dimaksudkan untuk meningkatkan kompetensi guru-guru PPKn SMP dengan memberikan pendampingan dan pelatihan agar memiliki wawasan dan keterampilan berkaitan dengan pemanfaatan dan pembuatan media pembelajaran berbasis ICT.

Pelatihan ini mendapat respon yang baik dari peserta. Selama pelatihan berlangsung, peserta fokus pada materi yang disampaikan oleh pembicara. Peserta juga memerhatikan setiap instruksi yang disampaikan oleh moderator. Adanya diskusi dan kegiatan tanya jawab membuat pelatihan ini menjadi lebih interaktif dan memudahkan peserta dalam memahami materi yang disampaikan. Keberhasilan dari pelatihan ini juga dapat dilihat dari hasil kuesioner yang ada pada tabel di bawah ini.

Tabel.1 Hasil kuesioner

\begin{tabular}{|c|c|c|c|c|c|c|}
\hline No & Pernyataan & & $\mathrm{S}$ & SS & $\mathrm{TS}$ & STS \\
\hline 1. & $\begin{array}{l}\text { Pelatihan ini menarik dan layak untuk } \\
\text { diselenggarakan lagi }\end{array}$ & & $11,2 \%$ & $87,8 \%$ & $1 \%$ & - \\
\hline 2. & $\begin{array}{l}\text { Pelatihan ini memberikan manfaat kepada saya untuk } \\
\text { memanfaatkan dan membuat media pembelajaran } \\
\text { berbasis ICT }\end{array}$ & $86,8 \%$ & $13,2 \%$ & - & - & \\
\hline 3. & $\begin{array}{l}\text { Pelatihan ini memberikan informasi-informasi baru } \\
\text { tentang media pembelajaran berbasis ICT serta } \\
\text { pemanfaatannya }\end{array}$ & $81,5 \%$ & $18,5 \%$ & - & - & \\
\hline 4. & $\begin{array}{l}\text { Pelatihan ini memberikan inspirasi kepada saya } \\
\text { untuk dapat memanfaatkan dan membuat media } \\
\text { pembelajaran berbasis ICT yang menarik }\end{array}$ & & $82,9 \%$ & $17,1 \%$ & - & - \\
\hline 5. & $\begin{array}{l}\text { Materi yang disampaikan cukup jelas dan } \\
\text { mudah dipahami }\end{array}$ & $62,9 \%$ & $36,6 \%$ & - & - & \\
\hline
\end{tabular}

Sebanyak $87,8 \%$ peserta menyatakan sangat setuju apabila pelatihan ini layak untuk diselenggarakan lagi. Tuntutan zaman yang mengharuskan guru PPKn SMP untuk dapat memanfaatkan dan menggunakan teknologi dalam kegiatan pembelajaran memang membutuhkan adanya pelatihan-pelatihan yang didesain khusus untuk pengembangan kompetensi mereka. Selain itu, sebanyak 86,8\% peserta setuju bahwa pelatihan ini telah memberikan manfaat kepada peserta untuk memanfaatkan dan membuat media pembelajaran berbasis ICT. Selanjutnya, $81,5 \%$ peserta setuju, dan 18,5\% peserta sangat setuju bahwa pelatihan ini memberikan informasi-informasi baru tentang media pembelajaran berbasis ICT serta pemanfaatannya. Dengan demikian, pelatihan ini memberikan inspirasi kepada guru PPKn SMP untuk dapat memanfaatkan dan membuat media pembelajaran ICT yang menarik, hal ini ditunjukkan oleh $82,9 \%$ peserta yang menyatakan setuju, dan $17,1 \%$ menyatakan setuju. Meskipun saat pelaksanaan pelatihan secara daring ini sempat mengalami masalah 
dengan koneksi jaringan, materi yang disampaikan cukup jelas, hal ini dapat dilihat dari $62,9 \%$ peserta yang menyatakan setuju, dan $36,6 \%$ sangat setuju.

\section{KESIMPULAN DAN SARAN}

Perkembangan zaman dan kemajuan teknologi telah mempengaruhi kehidupan manusia di segala aspek, termasuk pendidikan. Information and Communication Technology (ICT) atau Teknologi Informasi dan Komunikasi (TIK) telah dimanfaatkan sebagai media pembelajaran yang dapat menunjang terciptanya pembelajaran yang lebih interaktif efektif dan efisien. Pemanfaatan ICT dalam pembelajaran PPKn sangat penting, karena PPKn seringkali dianggap sebagai mata pelajaran yang membosankan bagi peserta didik. Apalagi di jenjang Sekolah Menengah Pertama (SMP), yang mana PPKn memuat banyak materi-materi penting dalam upaya membentuk warga negara yang baik. Oleh karena itu, melalui pelatihan ini guru PPKn diharapkan dapat meningkatkan kompetensinya, khususnya dalam membuat media pembelajaran berbasis ICT agar dapat menciptakan pembelajaran PPKn yang interaktif, efektif dan efisien. Pelatihan ini berlangsung dengan lancar dan mendapat respon yang baik dari peserta.

\section{DAFTAR PUSTAKA}

Andriani, T. (2015). Sistem Pembelajaran Berbasis Teknologi Informasi dan Komunikasi . Sosial Budaya : Media Komunikasi Ilmu-Ilmu Sosial dan Budaya, 128-150.

Bariyah, K. (2018). Upaya Meningkatkan Motivasi Belajar dengan Model Debat Untuk Meningkatkan Prestasi Siswa Kelas VIII SMP PGRI 8 Malang. LIKHITAPRAJNA. Jurnal Ilmiah. Fakultas Keguruan dan Ilmu Pendidikan , 59-73 .

Bhattacharjee, B., \& Deb, K. (2016). Role of ICT in 21st Century's Teacher Education. International Journal of Education and Information Studies., 1-6.

Budiana, \& Bakri. (2015). Pemanfaatn Teknologi Informasi dan Komunikasi dalam Pembelajaran Bagi Para Guru SMPN 2 Kawali Desa Citeureup Kabupaten Ciamis. Dharmakarya: Jurnal Aplikasi Ipteks untuk Masyarakat, 59-62.

Falahudin, I. (2014). Pemanfaatan Media dalam Pembelajaran. Jurnal Lingkar Widyaiswara, 104-117.

Ghavifekr, S., Abd Razak, A. Z., A. Ghani, M. F., Ran, N. Y., Meixi, Y., \& Tengyue, Z. (2014). CT Integration In Education: Incorporation for Teaching \& Learning. MOJET : The Malaysian Online Journal of Educational Technology, 24-45.

Karo Karo, I. R., \& Rohani. (2018). Manfaat Media Dalam Pembelajaran. AXIOM, 91-96.

Miftah, M. (2013). Fungsi dan Peran Media Pembelajaran Sebagai Upaya Peningkatan Kemampuan Belajar Siswa. Jurnal Kwangsan, 95-105.

Muslih. (2016). Pemanfaatan Media Pembelajaran Berbasis ICT pada Lembaga Pendidikan Non-Formal TPQ. DIMAS, 215-234.

Nursamsu, \& Kusnafizal, T. (2017). Pemanfaatan Media Pembelajaran ICT Sebagai Kegiatan Pembelajaran Siswa di SMP Negeri Aceh Tamiang. Jurnal IPA dan Pembelajaran IPA (JIPI), 165-170.

Rahim, M. Y. (2011). Pemanfaatan ICT Sebagai Media Pembelajaran dan Informasi Pada UIN Alauddin Makassar. Sulesana, 127-135. 
Rosdiana. (2016). Penggunaan Media Pembelajaran Berbasis ICT dan Pengaruhnya Terhadap Tingkat Kelulusan Ujian Nasional Siswa pada Sekolah Menengah di Kota Palopo. AlKhwarizmi: Jurnal Pendidikan Matematika dan Ilmu Pengetahuan Alam, 73-88.

Sakat, A. A., Zin, Z. M., Muhamad, R., Ahmad, A., Ahmad, A. N., \& Kasmo, M. A. (2012). Educational Technology Media Method in Teaching and Learning Progress . merican Journal of Applied Sciences , 874-878.

Singh, L., \& Jabeen, K. (2018). ICT for Delivering Quality Teaching-Learning Process. International Journal of Movement Education and Social Science, 342-349.

Sugiyono. (2011). Metode Penelitian Kuantitatif, Kualitatif dan R\&D. Bandung: Penerbit Alfabeta.

Suhartono, E. (2018). Perubahan Pola Pembelajaran PKn yang Tekstual ke Pola Konseptual (CTL). JTP2IPS, 1-12.

Suryani, N. (2015). Pengembangan Media Pembelajaran Berbasis IT. Prosiding Workshhop Nasional : Pengembangan ICT dalam Pembelajaran (pp. 1-14). Surakarta: Universitas Sebelas Maaret.

Suryani, N. (2015). Pengembangan Media Pembelajaran Berbasis IT. Seminar Nasional ICT Dalam Pembelajaran (pp. 1-12). Surakarta: Universitas Sebelas Maret.

Tafonao, T. (2018). Peranan Media Pembelajaran Dalam Meningkatkan Minat Belajar Mahasiswa. Jurnal Komunikasi Pendidikan, 103-114. 